\title{
TRUMP'S BORDER WALL: THE FLURRY LOSS OF IMMIGRANTS' RIGHTS AND RESHAPING IMMIGRATION LAW
}

\author{
Irma Febriyanti \\ Ph.D Program in American Studies, \\ Faculty of Cultural Sciences, Gadjah Mada University Yogyakarta \\ Email: irma.febriyanti86@yahoo.com
}

\begin{abstract}
ABSTRAK
Penggunaan istilah "hak asasi manusia Amerika Serikat (AS)" selalu mendatangkan kebingungan yang samar dan sering kali juga kerugian. Hal ini terjadi karena pengertian kontemporer advoksi hak asasi manusia telah terlibat pelanggaran kritik di negara lain dan klaim mereka atas pelanggaran hak asasi manusia yang diarahkan oleh AS, bukan kepada pemerintah AS itu sendiri. Presiden terpilih AS, Donald Trump, mendeklarasikan serangkaian kebijakan dalam dan luar negeri yang berkaitan dengan pelanggaran hak asasi manusia yang selama beberapa tahun terakhir ini telah mengalami kebuntuan. Salah satu kebijakan tersebut adalah U.S. Mexico border wall (tembok perbatasan AS - Meksiko) yang telah ditandatangani sebagai perintah eksekutif untuk "penghalang fisik yang tidak bisa dilewati" pada tanggal 25 Januari 2017 dan bersikeras agar Meksiko akan mengganti Amerika atas biaya tersebut. Tindakan ini menyebabkan pelanggaran hak asasi manusia dimana berbagai macam negara secara global telah serius menentang hal ini dan juga bahkan berusaha untuk memperebutkan hak asasi mereka atau warga negara lain yang membutuhkan dukungan.
\end{abstract}

ABSTRACT

The term of "U.S. human rights" has always been an elicited vague confusion and mostly takes place at a loss. It is because the contemporary notions of human rights advocacy involved the criticism abuses in other countries, and their claims of human rights violations were leveled by, not at, the U.S government. The elected President of the U.S., Donald Trump, declares a series of radical domestic and foreign policy related to human rights abuses that in recent years has fallen foul to congressional deadlock. One of the policies is about the US-Mexico border wall which was already signed as an executive order for an "impassable physical barrier" on January 25th 2017 and insisted Mexico will reimburse the U.S. for it. This action has led to human rights abuses where the world has seriously argued, moreover, violently contested over human rights to support them who need this the most.

Keywords: Trump, USA, Mexico, Immigrant Rights 


\section{Introduction}

Migration is a global phenomenon caused not only by economic factors, but also by social, political, cultural, environmental, health, education and transportation factors (Thet, 2003). There are push factor of less opportunities for the immigrants from Mexico in the socio-economic situation and also because of pull factors that exist in more developed areas like the well-developed United States of America. Generally, some combination of "push" and "pull" factors influence the decision to migrate, and individual decisions occur within a framework of internal and international structures that condition individual needs and the choices available (Papademetriou, 1983). Temporary moves may become permanent if reasons for leaving continue or are aggravated or the rationale for remaining is increased, as happens when families of labor migrants join them in the host country (Zolberg, 1983).

The migration history between the U.S. and Mexico has been affected by a heavy flow of migration for decades. An immigration itself impacts the individuals, their families and the greater economies of both regions, there are many factors that can motivate the individual from Mexico to immigrate to the U.S. A specific set of characteristics that can force some individuals out from their homeland is called the push factor, while the pull factor is when the U.S. can offer more opportunities which draws the individual and sometimes whole families out of their native country (Nelson, 2011).
The Mexican immigration issue is recently being brought back by Donald Trump, the new-elected $45^{\text {th }}$ President of the U.S. who is now effectively at war with undocumented migrants inside the US and those who attempt to cross the southern border without paperwork (Laughland, 2017). This border wall issue has shown us how the American people did not need human rights standards or international scrutiny to protect their rights. As in Bringing Human Rights Home: A History of Human Rights in the United States mentioned that many scholars and political scientist, who described themselves as "realists," expressed doubt that international human rights law could ever influence the behavior of superpower such as the United States. In another word, Trump's act on this border wall seems to deliver a message to the world that what he is doing at the moment is his right as a president of the U.S. and he does not need any other country's approval to do this.

Throughout the U.S. history, Declaration of Independence and the Bill of Rights has spoken human rights issues out loud both nationally and internationally. However, to bring this principle into practice is another story. The U.S. history is expected to embrace the concept that all people are endowed with certain inalienable or natural rights and have worked to bring its declaration into reality, but the fact has been delivering that not all people are fully human or have the same rights given based on their race, religion, and whatever background that seemed to be disliked by certain group of people with power in America. 
Being the President of the United States of America who more power over U.S. foreign policy, Donald Trump has said to make some controversial policies where some specializes in human rights law have publicly denounced Mr. Trump's policy pledges. One of them is the President of Mexico, Enrique Pena Nieto who rejects Trump's call for Mexico to pay for a border wall between the two countries. Believing to have a superpower influence in the international law \& economy and labeling the border wall in the name of 'national security,' Trump claimed that "we're in the middle of a crisis on our southern border", citing an "unprecedented surge" of undocumented immigrants from Central America that was harming both the U.S. and Mexico (Smith, 2017).

The new commander-in-chief considered that "a nation without borders is not a nation," wanting the U.S. to get back control of its borders, get back its borders. This border wall is said to save thousands of lives, millions of jobs and billions and billions of dollars. On the other hand, Enrique Pena Nieto said he "lamented" the plans for the barrier, adding that "Mexico doesn't believe in walls." The President of Mexico, Enrique Pena Nieto, said that he "lamented" the plans for the barrier, adding that "Mexico doesn't believe in walls" (BBC US \& Canada, 2017).

Mexico border is one in which fundamental human rights, environmental concerns, and the rule of law have been set aside to facilitate the construction of border walls which have, at most, symbolic value. The border wall's construction coincides with a rise in misinformation regarding the situation at the border, as well as the impacts and effectiveness of the border wall. As it was quoted from The Border Wall Violates Human Rights, the immigrants hope that the hearings that the Inter-American Commission on Human Rights holds will help to bring clarity to the situation, and will spur the United States to adopt rational border policies that promote human rights and reverse policies which currently violate human rights.

\section{Research Method}

This research is using a qualitative research which the researcher has studied from John C. Creswell's Qualitative Inquiry and Research Design: Choosing among Five Traditions. Using Creswell's qualitative inquiry, this research requires a form of interpretive inquiry in which the researcher needs to make an interpretation of Donald Trump's border wall and its effects to human rights issues and the perspective of the researcher is seen through human rights' perspective; an overview and analysis of the trends and patterns of human rights violations being perpetrated against immigrant and refugee communities by the U.S. government, local, county and state governments, employers and private citizen groups issued by the National Network for Immigrant and Refugee Rights (NNIRR) on immigration enforcement.

Under the auspices of NNIRR, this research is also taken from a new initiative form of NIRR that is Human Rights Immigrant Community Action Network (HURRICANE). This new form 
provides documents immigration raids and migrant deaths at the U.S.-Mexico border to mounting detentions and deportations. By having this report to analyze Trump's border wall, the researcher may find some policies, practices, measures and laws that violate international human rights norms and discuss how the human rights law is able to protect and uphold the rights of all immigrant and refugee families, workers and communities and focus on addressing the root causes of migration.

\section{Human Rights at Home and the International Human Rights Law}

As Donald Trump's vision for his presidency on immigration in the U.S., he mentioned that he will prioritize the jobs, wages and security of the American people. This first sentence of the vision taken from his website entitled Trumpence: Make America Great Again!, we can see that the words "American people" is delivering an ambiguity to the world. How will he define American people? Will the definition be different from the previous presidency?

As Cornel West has written in his Race Matters, he said that there are flaws in American society where they rooted in historic inequalities and longstanding cultural stereotypes (West, 1993). It means that as long as immigrants are viewed as a "them" or the "others," the burden falls on immigrants to do all the "cultural" and "moral" work necessary for healthy race relations. This subordination is probably just like Trump's intention on the border wall, the implication is that only certain Americans can define what it means to be American and the rest must simply "fit in."

Being immigrants in America should not be condemned since America has been expected to be the opportunity to show the world that its promise of liberty and freedom for all is not just a slogan, but also a reality. However, Trump as the latest president is trying to establish new immigration control to boost wages and to ensure that open jobs are offered to American workers first. He continues:

"Protect the economic well-being of the lawful immigrants already living here by curbing uncontrolled foreign worker admissions. Select immigrants based on their likelihood of success in the U.S. and their ability to be financially self-sufficient. Vet applicants to ensure they support America's values, institutions and people, and temporarily suspend immigration from regions that export terrorism and where safe vetting cannot presently be ensured. Enforce the immigration laws of the United States and restore the Constitutional rule of law upon which America's prosperity and security depend. Begin working on an impenetrable physical wall on the southern border, on day one. Mexico will pay for the wall" (The Trump Organization, 2017).

The effects of Trump's decision in the future may lead us to a tragic and perhaps unexpected story emerged one year after the Personal Responsibility Work Opportunity Reconciliation Act (PRWORA) which was vowed by the former President Clinton: refugees and immigrants from Asia were committing suicide in the face of losing their benefits (Fujiwara, 2005). Lynn Fujiwara said in her Immigrant Rights 
Are Human Rights: The Reframing of Immigrant Entitlement and Welfare that at the time of its passage on August 22, 1996, the welfare reform law ruled that nearly all non-citizen immigrants would be ineligible for Supplemental Security Income (SSI) (assistance for the elderly, disabled, and blind) and food stamps. By September 1, 1997, these non-citizens were expected to lose their SSI if they could not demonstrate proof of U.S. citizenship, 40 qualified quarters (10 years) of employment, or U.S. veteran status. An estimated 500,000 noncitizens were expected to lose their SSI benefits, and nearly 1 million were to lose their food stamps.

The loss of immigrant rights in the U.S. may create a racial and gendered politics surrounding the move to end welfare entitlement for non-citizens operated from a discourse that characterized immigrants as socalled "underserving foreigners, abusing the system and taking resources from hard-working Americans." Contemporary immigrant scholars argue that the narrative of a national "immigration problem" targeted poor immigrant women, accusing them of abusing an overlygenerous welfare system (Adalberto Aguirre, 1997).

The first implementation of reduced benefits to non-citizens was planned for September 1997, one year after the passing of the Personal Responsibility Act. For a substantial proportion of immigrant recipients, losing SSI would mean losing lifesustaining support needed for continued convalescent care, skilled nursing facilities, in-home health care, and basic nutrition. Families began to flood social service agencies and community organizations, panicked about how they were going to take care of their physically or cognitively disabled elderly parents. Reports of suicides by elderly and disabled immigrants sprang up across the country, with three Southeast Asian women, an elderly man from China, and an elderly man from Mexico each leaving behind messages that they did not want to become burdens to their families. Community-based agencies implemented suicide hotlines with language accommodations for suicidal immigrants (Fujiwara, 2005).

It was that kind of crisis which leads us to human rights violation, then to nation-wide grassroots mobilization efforts and visibility campaigns, intended to gain public attention and make legislators aware of the immediate and potentially far-reaching harm created by welfare reform to the nation's politically most vulnerable.

\section{Building a Wall as the Trump's Triumphant over Mexico}

Throughout his political campaign in running for the presidency, Donald Trump made a promise about building a wall on the southern border between the U.S. Mexico throughout an election campaign which is characterized by xenophobia, and one he has now underlined with a few flicks of the presidential pen. This strategy of renewing a foreign policy about immigration has led us to understand how hard Trump wanted to save the federal budget and seeing this 
humanitarian issue in the eye of merely a business.

It seems like President Trump and his new policy tries to show us the upcoming U.S. government's strategies which is range from justifying immigration enforcement as a national security measure, to directing billions of dollars into private security firms. U.S. immigration services and enforcement policies are shaped by the drive to expand policing, prison building and to criminalize, detect, jail and deport immigrants with impunity.

As a result, just like the Human Rights Immigrant Community Action Network (HURRICANE)'s report in its Over-Raided, Under Siege: U.S. Immigration Laws and Enforcement Destroy the Rights of Immigrants: the U.S. immigration enforcement and border control policies and strategies are fueling a humanitarian crisis that disproportionately impacts immigrant communities. Instead of upholding the rights of immigrants or providing safe and legal means to immigrate, U.S. immigration and border control strategies deliberately force migrants to risk their lives, causing untold suffering and the death and disappearance of hundreds of migrants every year on the U.S.-Mexico border. This crisis follows migrants wherever they go on their journey to interior communities. They face escalating attacks fueled by the Department of Homeland Security's strategy of almost exclusive reliance on exclusion, detention and removal to "solve" the undocumented problem (García, Tactaquin, Rancaño, \& Rivas, 2008).

Over the past few years, immigrants have been increasingly marginalized and denied public services in a new way: they are being scapegoated and collectively punished for many of the U.S.'s social and economic ills. Immigrants, especially the undocumented, are blamed for the fiscal crisis. Then, under the guise of immigration control and national security, federal, state, county, and local governments propose and approve policies and ordinances to cut back and privatize public services and gut civil liberties.

Immigrants have become especially vulnerable to abuse and violence. Whether they are documented or undocumented, immigrants are now the almost exclusive scapegoat for the faltering economy, the threat of terrorism, the deterioration of services and the social problems afflicting the U.S. In this officially condoned anti-immigrant climate, racial profiling, exploitation in the workplace, hate violence and multiple public policies are being used to deliberately force immigrants to leave or exist in the shadows.

\section{Mexico in America: Immigrant Rights and the Great Loss at the Border}

The coming age of social movements such as the labor movement of the $1930 \mathrm{~s}-40$ and the civil rights movement of the 1950s-60s may sound similar to the protest of thousands of immigrants rights supporters on May 1, 2006 which was called as "2006 United States immigration reform protests." Just like one of Martin Luther King, Jr.'s supporters who carried a sign proclaiming "I Am a Man" to support 
their fight for labor, civil, and human rights, immigrant rights groups also invoked a range of moral justifications (Ontiveros, 2007), the 2006 immigration protests were also trying to be seen as merely human beings with legal rights to live peacefully in America. The protests began in response to proposed legislation known as H.R. 4437, which would raise penalties for illegal immigration and classify undocumented immigrants and anyone who helped them enter or remain in the US as felons.

The 2006 immigration protests proclaimed their human rights, workers' rights, citizenship rights, and civil rights. Immigrants, especially immigrant workers and their families, might as well draw on the language of the Thirteenth Amendment. This issue of the Thirteenth Amendment is brought by Maria L. Ontiveros in her journal entitled Immigrant Rights and the Thirteenth Amendment which provides a compelling moral and analytical description of the immigrant rights issue. She said that issue a case can be made that that the Amendment prohibits abusive work relationships that interfere with workers' rights, citizenship rights, human rights, and civil rights in ways similar to the institution of chattel slavery.

\section{Conclusion}

The argument seems to appear that immigrant rights organizations intentionally positioned some immigrants as deserving and others as not deserving, but rather that a constant dilemma remains for social movement actors to gain social change for specific groups without reifying existing conservative notions that "not all are deserving of economic support." Faced with a state of desperation, immigrant rights advocates challenged what seemed an impenetrable antiimmigrant public and Congress. The construction of "people categories," then, consisted specifically of the elderly, disabled, and Southeast Asian refugees who raised moral dilemmas and emotional responses requiring a policy change.

Since the U.S. now mandatorily detain any migrant that is caught crossing the border without documentation, the order has to pave the ways for a huge expansion of detention facilities at the southern border and is likely to have devastating humanitarian effects. It was nearly 60,000 unaccompanied minors and close to 80,000 families were apprehend at the border in 2016, the vast majority of whom care from countries in Central America plagued by violence. Then the groups of migrants, who received a degree of flexibility under the Obama administration, will be kept in detention by order.

The effects may not merely about the lack of claims for asylum, but also poor medical standard, facilities and deportation. This deportation perhaps in violation of America's legal obligations under the UN Refugee Convention. This Trump's orders implement aggressive enforcement action inside the country which is away from America's border. The ending of catch-and-release by Trump orders acknowledge that there will be an essential broadening the definition of serious criminality, giving Immigration 
and Customs Enforcement (Ice) agents a vast remit to target almost anyone within undocumented communities and perhaps even those holding visas as the order simply targets "removable aliens" - a broad, catchall term that could encompass non-citizens as well.

Thus, while my research demonstrates the critical role of strategic framing in influencing social policy, we cannot ignore the contextual limitations and constraints in bridging rhetorical strategies for broader immigrant and welfare rights campaigns. Immigrant rights groups continue to struggle to achieve the political traction needed to shift the increasing loss of assistance for welfare recipients and of legal rights for noncitizens. This struggle faces even greater challenges as our current economic and political climate of "threat" and "terror" rejects the notion that non-citizens should have entitlement to public benefits.

\section{References}

Adalberto Aguirre, J. (1997). Nativism, Mexican Immigrant Workers, and Proposition 187 in California. In J. Adalberto Aguirre, \& C. F. Hohm (Ed.), California Social Problem (pp. 142-153). New York: Addison Wesley Longman, Inc.

BBC US \& Canada. (2017, January 26). Mexico: We will not pay for Trump border wall. Retrieved from BBC News:

http://www.bbc.com/news/worl d-us-canada-38753826

Fujiwara, L. H. (2005). Immigrant Rights Are Human Rights: The Reframing of Immigrant
Entitlement and Welfare. Social Problems, Vol. 52, No. 1, 79-101.

García, A., Tactaquin, C., Rancaño, V., \& Rivas, L. (2008). Over-Raided, Under Siege: U.S. Immigration Laws and Enforcement Destroy the Rights of Immigrants. Berkeley, CA.: Chimes Printing.

Laughland, 0. (2017, January 26). US could face human rights crisis after Trump's xenophobic immigration order. Retrieved from Guardian News and Media Limited: https://www.theguardian.com/u s-news/2017/jan/26/trumpimmigration-border-detentionmigrants-catch-release

Nelson, S. R. (2011). The Immigrant Experience: Mexico and Central America to the United States. California: California Polytechnic State University.

Ontiveros, M. L. (2007). Immigrant Rights and the Thirteenth Amendment. New Labor Forum, Vol. 16, No. 2 , 26-33.

Papademetriou, D. (1983). Rethinking International Migration: A Review and a Critique. Comparative Political Studies, 469-498.

Smith, D. (2017, January 26). Trump signs order to begin Mexico border wall in immigration crackdown. Retrieved from Guardian News and Media:

https://www.theguardian.com/u s-news/2017/jan/25/donaldtrump-sign-mexico-borderexecutive-order

The Trump Organization. (2017, January 26). Immigration: DONALD J. TRUMP'S VISION. Retrieved from Trumpence: Make 
America Great Again!:

https://www.donaldjtrump.com/ policies/immigration

Thet, K. K. (2003). Pull and Push Factors of Migration: A Case Study in the Urban Area of Monywa Township, Myanmar.

West, C. (1993). Race Matters. Boston: Beacon Press Books.

Zolberg, A. R. (1983). Contemporary Transnational Migration in Historical Perspective: Patterns and Dilemmas. In M. M. Kritz, U.S. Immigration and Refugee Policy. Lexington, Ky: Lexington Books. 